\title{
An Analysis of Loan Repayment Performance in Government Microcredit Programs: A Case of Small Enterprises Development Corporation (SEDCO) in Zimbabwe (2009-2012).
}

\author{
Gumisai Jacob Gutu \\ Great Zimbabwe University,P O Box 1235, Masvingo, Zimbabwe \\ Moses Nyakuwanika \\ Great Zimbabwe University,P O Box 1235, Masvingo, Zimbabwe \\ Kudzanayi Matowanyika \\ Chinhoyi University of Technology, P Bag 7724, Chinhoyi, Zimbabwe \\ Maureen Unganayi \\ Chinhoyi University of Technology, P Bag 7724, Chinhoyi, Zimbabwe
}

\begin{abstract}
The study endeavoured to analyse loan repayment performance of government microcredit programs. The study was motivated by the fact that government microcredit programs perform poorly because of slow repayment and high defaults. Loan repayment performance of Small Enterprises Development Corporation (SEDCO) for the period 2009 to 2012 was reviewed checking whether the institution's credit policy was being effectively implemented to ensure a positive repayment performance. A case study approach was adopted, and questionnaires were administered to thirty Small to Medium Scale Enterprises (SMEs) in Harare, Zimbabwe and ten to SEDCO staff working directly with loans and also top management was interviewed to provide information on loan repayment. The study revealed that most borrowers fail to make repayment on time or default because of poor business performance, having many dependents to take care of and/or diversion of funds to unprofitable use. On screening potential borrowers, it was found that clients with fixed assets to pledge as collateral, project and business plan were given high priority. It was also found that credit policy implementation was poor as a result of lack of working capital. It was recommended that loan screening process should be revised, repayment period should be revisited for it to be client specific than a "one-size-fit-all" policy for financially viable projects which require a higher repayment period, client follow ups should be intensified and improvement of the loan management information system. Finally SEDCO has to educate borrowers that government microcredit programs are not extended to them as grants but loans which should be paid back to the lender.
\end{abstract}

Key words: Government Microcredit programs, Loan repayment and collateral

\section{INTRODUCTION}

According to Deacons (2007), most developing countries like Zimbabwe where the production and service sectors are at their infant stage, the role of Small to Medium Scale Enterprises (SMEs) is significant in terms of employment creation, quick production response, and use of 
local resources and as a means of developing indigenous entrepreneurial and managerial skills for a sustained growth need. For SMEs to grow up to large scale level, the need for formal credit sources is indispensable because formal financial sector has the capacity to meet their growing credit demand, which the informal sector is incapable to supply.

This has led the Government of Zimbabwe to form an organisation called Small Enterprises Development Corporation (SEDCO) with the sole responsibility of meeting the financial needs of SMEs in cases where the same have failed to secure loan from the formal banking sector.

\section{BACKGROUND TO THE RESEARCH}

The Small Enterprises Development Corporation (SEDCO) was established in 1984 as a government owned program that would solve the problem that SMEs faced at the time. The program's objective was to provide financial support and an opportunity to gain commercial experience. Over time, loans were extended to assist in business expansion and were focused mainly on micro, small to medium projects (SEDCO’s Five Year Plan 2010 - 2015).

Since inception, SEDCO has provided financial assistance to SMEs in all provinces of Zimbabwe. Individuals, partnerships, small companies and cooperatives have so far benefited from this program. SEDCO has been enjoying some growth over the past years but is now encountering some problems in trying to recover its loans because borrowers are taking long to meet their financial obligations to the organisation. This is indicated by high loan default rates and high bad debts being written off at financial year ends. According to the SEDCO's Credit Policy, repayment is designed in such a way that the capital amount is repayable in equal monthly instalments of interest and principal debt combined.

Some borrowers become defaulters because of poor managerial skills, lack of education and they do not keep financial accounts and making it difficult for financial institutions to monitor their operations Fillder (2010). There has been deterioration in recent repayments rates and liquidity as indicated by the financial statements of SEDCO. According to the SEDCO's Annual Reports (Year 2009-2011) the loan recovery rate has decreased from 56\% to 31\% in the period 2010 -2011. This may be as a result of lack of compliance to the credit policy.

The default rates mentioned above seems paradoxical because only a small number of borrowers accessed the credit from SEDCO while a considerable portion of the eligible borrowers are in default. This led the research to question whether the screening criteria is efficient and necessitated the need for making an empirical investigation on the factors behind loan repayment performance and assessment of the loan repayment performance so that the credit policy can be revised in such a way that will reduce loan default and improve the liquidity position of microcredit financial institutions.

JUSTIFICATION TO THE RESEARCH: The research will help the financial institutions (such as SEDCO) to evaluate its criterion of choosing eligible clients so as to reduce defaults. It will also help the financial institutions to identify the major characteristics that distinguish credit worthy borrowers and defaulters.

Eligible borrowers could also improve the financial constraint of SMEs which are potentially efficient but could not be able to fulfil the lending requirements by making timeous repayments of their loans. 


\section{Strategies To Minimise Default}

\section{THEORY AND EMPIRICAL STUDIES}

Huppi and Feder, (2009) suggested that a strategy for dealing with default is group lending. This is the collective coming together of individuals for the purpose of borrowing and it is useful in a number of ways, which includes pressure from other group members that obliges the members to work within agreed values and norms. Although studies show that such schemes work well if groups are homogeneous and jointly liable for defaults, the practice of denying credit to all group members in case of default is the most effective and least costly way to enforce joint liability.

The Grameen Bank (2000) has identified fourteen different microfinance models. Among the fourteen three of the models are; Rotating Savings and Credit Association (ROSCAs), the Grameen Bank solidarity group and the village banking models.

- Rotating savings and credit association: This is when a number of people come together to make regular cyclical contributions to a common fund, which is then given as a lump sum to one member of the group in each cycle.

- Grameen solidarity group model: This model is based on group peer pressure whereby loans are made to individuals in groups of four to seven. Group members collectively guarantee repayment, and access to subsequent loans is dependent on successful repayment by all group members. This model has proved effective in deterring defaults as evidenced by loan repayment rates attained by the Grameen Bank which uses this type of model. They also highlight that this model has contributed to broader social benefits because of the mutual trust arranged at the heart of the group guarantee system.

- Village banking model: Village banks are community managed credit and savings association arranged established by NGOs to provide access to financial services, build community self-help groups, and help members accumulate savings

There is also the three Cs of microcredit which if adhered to may help to reduce default when providing microcredit and these are: character, capacity, and capital.

I. Character -refers to the way a person has handled past debt obligations. Paying attention to character includes determining the borrower's credit history and background, intergrity, and reliability to pay credit debts.

II. Capacity- involves determining how much debt he or she can handle comfortably by analysing income streams and identifying any legal obligations that could interfere with repayment.

III. Capital- refers to a borrower's current available assets, investments that could be used to pay debt if income is unavailable.

The theoretical analysis behind the predictive indicators of loan default for SBLs can be summarised in the diagram below:

Experience has shown that funding agencies' microfinance interventions produce better results when design, reporting, and monitoring focus explicitly on key measures of performance. The five basic tools to measure performance of microfinance institutions are:

I. Outreach- how many clients are being served?

II. Client poverty level- how poor are the clients 
III. Collection performance- how well the financial institution is collecting its loan

IV. Financial sustainability- is the microfinance profitable enough to maintain and expand its services without continued injection of subsidised donor funds?

V. Efficiency- how well does the financial institution control its administrative costs?

\section{Theoretical Arguments on Loan Repayment Performance}

There are several factors behind high default in microcredit finance. Some people argue that the characteristics of the SME Company make the cost of administering credit high compared to the return on loan. SMEs possess poor management skill, often with little experience and training, they are usually undiversified, they are usually infant businesses, with poor status and keep incomplete financial records, they do not have collateral security, they may be reluctant to expand their business lines for reasons of expense, loss of control and increased statutory requirements. These features of SMEs provide little incentive for any aggressive loan recovery mechanisms Okpukpara (2009), Ojiako and Ogbukwa (2012).

Loan default is as a result of the failure by financial institution to play its role in loan disbursement and credit management. Screening credit worth clients requires a lot of time and resources to evaluate each and every client. A mistake made on the evaluation of borrowers or the use of inappropriate credit policy may increase the total risk of the transaction Yunus (2003 Yunus (2003) found that unprofessional practices lead to defaulting and thus increasing credit risk.

Political factors also have a bearing on loan repayment performance because it affects the credit systems from the screening stage, disbursement up to the recovery stage Afolabi (2010). This is because when the government is involved in credit programs, recipients tend to fail to distinguish between loans and government grants.

In a study by Kohansal and Mansoori (2011) on the factors affecting loan repayment performance with reference to the Khorasan-Razavi province in Iran, it was revealed that large rates of default have been a perpetual problem in most agricultural credit schemes organised or supported by the governments. Most of the defaults arose from poor management procedures, loan diversion and unwillingness to pay loans. For this reason lenders devise various institutional mechanisms aimed at reducing the risk of loan default. The mechanisms include pledging of assets as collateral, third party credit guarantee (guarantors), use of credit rating agencies and collection agencies.

Kohansal and Mansoori (2011) in recent theoretical and empirical work in economics have established that credit markets in developing countries work inefficiently due to market imperfections. A number of market inadequacies which lead to defaulting and these inadequacies include:

I. Interest rate ceiling usually imposed by the government

II. Monopoly power in credit markets often exercise by informal lenders

III. Large transaction costs incurred by borrowers in applying for loans

IV. Moral hazard problems

Awoke (2011) went on to say that in the context of providing credit to the poor, what is required is institutional innovation that combines prudent and sustainable banking principles with effective screening and monitoring strategies that are based on physical collateral.

Glennon and Nigro (2011) analysed small loan repayment and found out that defaults are time sensitive and are particularly affected by the changing economic climate during the life of a loan. The probability of default in SBLs datasets peaks after six to twelve months, which 
suggest that any model that can be used for determining loan repayment should include time sensitive variables. In addition they found out that long term loans are more sensitive to changes in the business cycles than short term loans and that corporate structure has a large influence on the odds of default.

On the other hand, lending to better-off borrowers result in higher delinquency rates, suggesting that when borrowers have better alternatives, they place less value on the program (Wenner, 2011). This shows that a selection bias can arise if better-off borrowers go to institutions like SEDCO when they have riskier projects.

According to a research by the Grameen Bank (2003, one of the main reasons for low defaults payment among the poor is that lending to them is based on group lending model. In group lending model, the borrower and the group are jointly responsible for the loan. This joint responsibility has been argued that, it induces group members to self-select each other and also provides incentive to borrowers and the group members, to choose a safe investment project. Thus, group-lending reduces not only the problems of moral hazard, but also provides the incentive for peer-monitoring or peer pressure among group members, which leads to good rates of repayment of the loan. Group pressure and monitoring thus seems to be a substitute for collateral and reduces the probability of loan default.

In an attempt to empirically analyse the factors affecting loan repayment performance of smallholder farmers Haile (2011) used the Two Limit To bit Model using information obtained at the household, community level and group level. The result based on 140 randomly selected farm household users of credit in two agro ecological zones of Eastern Hararghe indicated that loan beneficiaries can be classified into two main categories namely:

I. Defaulters

II. Non defaulters

The results of the research revealed that a significant mean difference between defaulters and non-defaulters in terms of education, borrowing experience and credit use, remoteness from credit source, technical assistance, total annual income, livestock units, and total land. Moreover, the existence of other sources of income, natural disasters like crop and livestock disease, and education level systematically has effect on loan repayment. However other variables such as age, family size, amount of loan, were not significant between the defaulters and non-defaulters.

Ajiambo, (2010) mentioned that the most dangerous problem a microcredit program faces is repayment default. The main cause of loan default depends on the following:

- Formal lending program directed towards the poor faces a number of challenges. This is a problem because poor borrowers generally do not maintain any accounts of the past business activity or furnish any documented business plan for the use of the loans.

- The second problem is screening or the selection to distinguish the good (creditworthy) borrowers from bad (not-so-creditworthy) borrowers.

- Third, the funding agencies may not be able to monitor and ensure productive usage of the loans. The challenge here is determining whether the loan application is for the purpose of expanding a profitable on-going business or whether it will be channelled into unprofitable operations.

In an investigation by Roslan (2009), loan repayment of Agrobank depends on the borrower characteristics, project characteristics and loan characteristics as given below: 
Borrower characteristics: Gender, Marital status, Race, Level of education, Age, Occupation, Number of dependents, Experience, Membership in business society and Training

Project characteristics: Ownership structure of the project, Types of project, Distance of the project to the bank, and Revenue from the project and,

\section{Loan characteristics: Amount of the loan and Length of the repayment period}

In a research by Mohammed (2011) on access to formal and quasi-formal credit by smallholder farmers and micro-enterprises in Zanzibar, the reasons for poor repayment performance are: Poor loan appraisal system, Attitude of borrowers towards government funding, Enterprises failure due to technical reasons and natural disasters, Weak management capacity, Marketing problems, Poor loan follow up systems and Lack of collateral or security

Koopahi and Bakhshi, (2010) used a discriminant analysis to identify defaulter and nondefaulter farmers of agricultural bank recipients in Iran. Results of the research showed that use of more efficient machinery, length of repayment period, bank monitoring on the use of loan had significant and positive effect on the credit repayment performance. Moreover level of education of the loan recipient and length of waiting time for loan recipient had a significant and negative effect on repayment.

Pischke (2012) identified two problems as the major causes of poor loan recovery performance: credit project design and project implementation problems.

Credit project design: Debt versus equity, Realism versus aspiration - how realistic the projection of the project design is? Expected value versus dispersion - detailed consideration of the variety of results which occur in the field, Book keeping convenience versus borrower cash flow patterns, Collection mechanism, Institutional scope and the range of services offered by it and Interest rates

Credit project implementation: Low service levels, Coordination, Access - information problem and lack of decision making experience in lending to specific target groups and Financial recording

Norrel (2011) carried out a research on the ways to reduce arrears in MFIs (Micro-Finance Institutions) and the research indicated that the main causes of arrears by SMEs are:

- SMEs often test the MFI to see if they are serious about collecting loan repayments because they know that most of them are government funded.

- Clients may use the loans extended to them to solve family problems

- If loans are too larger than the cash needs of the business, extra funds may be diverted to other non-profitable personal uses.

If loans are issued in terms of favouritism, clients may attempt to delay payment or default. This is because they feel that their friends in the MFI may influence the organisation to write off the loan rather than taking legal action towards the defaulter.

\section{Factors To Consider When Screening Loan Applicants}

According to the SEDCO's credit policy (revised 2011) the following is the list of requirements for loan application:

I. A bankable business plan or proposal with cash flow projections for the next twelve months 
II. Minimum equity contribution of $15 \%$ of total cost (new business) or proof of past investment into the business (on-going business concern)

III. Documents to confirm legal status of a business for example certificate of incorporation, Articles of Association, Memorandum of Association, CR14 of the directors

IV. Relevant operating license

V. Proof of operating premises

VI. Proof of ownership of assets pledged as collateral

VII. Pro-forma invoices of items to be purchased or agreement of sale where the proposal is to purchase a going concern

VIII. Income statement and statement of financial position for the past two years or any part thereof

IX. Bank statement for the past three months and a bank report

X. Trade references from previous and current creditors

XI. Director/owner/management curriculum vitae

XII. Photocopy of the directors /owners national identity cards

In a descriptive analysis carried out by Okpukpara (2009), on the strategies that can be adapted to effectively deliver loans to small scale enterprises in rural Nigeria, the results show that applicants with higher experience are more likely to obtain loans than those with limited experience. Okpukpara (ibid 2009) went on to say the enterprises operated by females were likely to get a loan than those operated by male counterpart. The writer further says that the major factors that are considered by financial institutions in issuing loans is history of past loan, type of enterprise, experience of owner of that business, gender and ownership of fixed assets.

In a research on the analysis of loan repayment among small scale farmers by Afolabi (2010) recommended that credit institutions or lending agencies should look out for the socio economic characteristics (age, sex, marital status, level of education) that significantly influence loan repayment before granting loans and advances to small-scale farmers to reduce the incidence of loan delinquencies and default.

In recent research carried out by Roslan and Karim (2010) on the Agrobank, for one to access a loan from the bank s/he has to fill up an application form as well as to submit a viable business proposal. However Agrobank policy is contrary to that of SEDCO in that client does not have to provide any collateral to support the application. Roslan and Karim (2010) added on that an applicant has to wait for about a week to get the loan approval. Approval is based on the viability of the project, particularly in regard to the projects securitisation of cash flow. Furthermore, the chances of getting approval are usually higher if the client has a project underway than when the project is at the start up stage.

However, the idea by Coravos (2010) tends to differ as the issue of risk was considered to be the major factor to consider when screening loan applicants. Before a loan is extended to an applicant, there is need to carry out a risk analysis. This means that there is need to look at the risk associated with lending to a client before and after disbursement. The higher the credit risk the more unwilling the financial institution will be to extend a loan to an applicant. Loan officers should perform a qualitative risk analysis when they interview potential borrowers, look over the business plan and review past financial history (Coravos, ibid 2010).

Coravos (2010) also highlighted that one of the most predictive measure of repayment is the personal credit score. The borrower's personal credit history is often deemed more important 
and predictive of repayment than the business plan or feasibility of the idea (Cowan and Cowan (2006)). The idea of credit scoring agrees to that suggested by Horne, (2002).

\section{The Credit Scoring Approach In Screening Loan Beneficiaries}

According to Horne (2002), the credit scoring system is a method used to decide whether to grant credit by assigning numerical scores to various characteristic related to credit worthiness. Its advantages include speed, accuracy, constancy and reduced personal cost (www.icmsglobal.com) accessed on 12/08/2010. There are two types of credit scoring models namely judgmental and statistical models.

- Judgmental scoring is based on factors such as previous payment experience of the client, bank and trade references, ratings of the credit agency and financial statement ratios. These are scored and weighted to produce an overall credit score. It also involves the use of credit policies and decision making process.

- Statistical scoring is much the same way as judgmental except that the factors to be scored and weighted rely on statistical methods rather than experience and judgment. The statistical model (FICO score) was first developed by Fair Isaac in 1958.

The FICO score model provides a snapshot of risk that banks and other institutions use to help make lending decisions. Applicants with higher FICO scores will be offered better interest rates on mortgages as well as higher credit limit amounts (www.federalreserve.gov)

In United States a credit score is a number representing the credit worthiness of a person, the likelihood that an individual will be able to make payment. Credit scores are used by lenders to evaluate the potential risk posed by lending money to certain individuals.

Chandra (2012) outlined how the numerical system that can be applied by an organization. Below are the steps:

1) Identify influences relevant to enable credit evaluation.

2) Assign weights to these influences that replicate their relative importance.

3) Rate the customer on various factors using a suitable rating scale .i.e. five point scale.

4) Multiply the factor rating with the factor weight to get the factor score. This should be done for each factor identified.

5) Find the summation of all factor scores to get the total customer rating index.

6) Classify the customer basing on the rating index.

Norell (2011) agreed with other researchers and said that there are various sources of information regarding a potential client's credit worthiness which include:

I. Your own experience with the client

II. The experience of other creditors

III. The assessment of a credit agency

IV. A check with the customers bank

V. The market value of the clients securities

VI. An analysis of the clients financial statements (financial ratios and trends).

Moreover Mester(2011) argued that the applicants' monthly income, financial assets, outstanding debt, employment tenure, homeownership, and previous loan default or delinquencies as predictive of loan default for SBLs. Moreover, firms that handle a large volume of credit information often use a formal system for combining the various sources into an overall credit score, for example use the Z-score model. The scoring system is intended to prescreen credit applications. When a firm has a small, regular clientele, the credit manager can easily handle the process informally and make a judgement by assessing the five C's of credit:

I. The clients character 

II. The clients capacity to pay
III. The customers capital
IV. The collateral provided by the client
V. The condition of the client's business

After all the evaluation, decision can be made on whether or not to grant credit. The decision to offer credit depends on the probability of payment. Credit should be granted if the expected profit from doing so is greater than the profit from refusing.

\section{What is a credit policy?}

Bullivant (2013) defined a credit policy as a document that specifies the course of action for granting credit and recurring credit activities. The credit policy need to be revised and monitored on a regular basis to take account of the dynamic conditions of the market, company strategies, rivalry activities, and financial needs. Bullivant (2013) pointed out that a credit policy is a fundamental requirement of sound credit management practice, and should serve the following purposes:

- Define the aims of credit extension in the context of corporate strategy and organisation structure.

- Define the authority and responsibility for granting credit, establishing and varying terms and the timing of collection terms

- Deliver documented processes in relation to the above that can be communicated to staff

- Stipulate performance levels and monitoring activities for credit staff

- Strengthen "one company-one customer" philosophy throughout the organisation

A credit policy is a clear written guideline that set:

- the conditions and terms for supplying goods and services on credit,

- customer qualification criteria,

- procedures for making collections

- steps to be taken in case of customer delinquency (www.businessdictionary.com) accessed on 12/08/2010.

The Merriam-Webster Online Dictionary (www.merriam-webster.com) accessed on $16 / 08 / 2010$ defines the credit policy as a guideline taken by a business in granting, monitoring and collecting the cash for outstanding accounts receivable.

A credit policy is the heart of any credit department. Denis (www.coveringcredit.com) accessed on 12/08/2010 emphasized that businesses should have a written credit policy because it ensures continuity, consistency, can be used as a training tool and also to evaluate job performance against established standards. This follows that a credit policy should be well understood by everyone directly affected i.e. business analysts and credit people. A credit policy should be considered a contractual agreement and can be revised annually.

A typical credit policy should neither be too liberal or too restrictive. According to Pandey (2010) a liberated credit policy will increase the amount of sale and profitability. But risk will also increase with increase in sales. This is graphically presented below:

Fig 2.1: Credit policy optimisation

Source: Pandey (2010) 
If loans are issued to those clients whose capacity to pay is poor, then it is possible that some amount will become defaulted. On the other hand, if company's credit policy is strict, then it will improve the liquidity position and security, but negatively affect the profitability. So, finance manager should create a credit policy at optimum level where liquidity and profitability are equal.

\section{WHY A CREDIT POLICY IS REQUIRED?}

According to the FERMCA Credit Policy by Bullivant (2013), acredit policy is necessary to show the company's intended way of doing business and avoid confusion and potential misunderstanding. Successful companies have long set down their preferred operational approaches to the credit function and how it fits into the organisation. Bullivant (2013) further said that a credit policy lays out the financial measurement process from the initial budget to monthly reports of actual results compared to that budget as follows:

- a credit policy statement including

- the part that credit plays in overall sales and financial objectives, and

- the responsibility of various job holders

- annual and monthly objects showing:

- criteria (defaulters, bad debts) and

- ratios and percentages

- annual budgets for monthly defaulters and credit department costs

- organisational charts to show credit jobs and their connections to other functions

- ways for credit evaluation and collections; and

- credit managers monthly report showing:

- Repayment results and variance from budget with reasons; and

- Credit department costs and explanation of variance from budget.

Mishi and Kapingura (2012) went on to say that monthly, weekly, reporting illustrates the effectiveness of the credit policy and its adherents. Trade credit terms are invariably expressed in days, so the reporting of outstanding debts in terms of days is the usual key performance indicator. The credit policy should stipulate how reporting should take place, but it should always incorporate the key four elements of:

- Days sales outstanding(DSO)

- Total amounts due as a percentage of total debtors

- Age of amounts due within the total overdue

- Disputed debts

Moreover Pandey (2010) suggested that for proper implementation of the credit policy to be effective there is need for an institution to devote a lot of working capital to this exercise. Mishi and Kapingura (ibid, 2012) pointed out that client follow ups, generation of account statements, training of the credit control staff and client monitoring requires a strong financial backup.

\section{Loan Repayment Indicators}

In a research carried out by McCann and McIndoe-Calder (2012), who cited Chan-Lau (2006) pointed that there are generally two default models in corporate lending namely:

i. Fundamental based models: These use borrower-level balance sheet information as behavioural drivers to defaulting. The information that can be used in this model include levels of leverage, liquidity, turnover, probability and relative loan size to asset levels as well as sector specific effects and soft information like age of the business.

ii. Market outcome based: This model uses market capitalisation data on publicly trading corporations to predict corporate default of bankruptcy. 
However another study carried out by Gebeyehu (2009), on the National Bank of Ethiopia, indicated that loan recovery rate and arrears to outstanding ratio are the major measures of loan repayment performance of loan portfolio of a financial institution.

Loan recovery rate signals the financial position of the lending unit. This includes its capital level, profitability and liquidity or cash flow management. The basic formula for calculating loan recovery rate is:

Loan recovery rate $=$ total loan collected Total loan demand
Arrears to outstanding ratio $=$ loan in arrears loans outstanding

The arrears to outstanding ratio show the percentage by which the loans that are due for repayment as compared to the total loans that have passed the due date.

According to Ajiambo (2010) repayment performance is determined by average repayment delay and default rate. These ratios are the major indicators that are employed by the World Bank in measuring repayment performance.

\section{The Research Design}

\section{MATERIALS AND METHODS}

Ajiambo (Kenya, 2010) used a comparative design when carrying out a research on causes of default. In a similar research carried out by Roslan (2009) on determinates of loan repayment in Malaysia a survey research design was used among Agrobank microcredit schemes borrowers in eighty-six branches throughout Malaysia. Another researcher Nawai (2010) used a case study research design in his research on repayment performance in microcredit programs and this design aimed at providing insight into loan repayment performance. Moreover Haile (2011) in the research carried out in Ethiopia, Haraghre a descriptive approach was used to investigate on the factors affecting loan repayment performance on smallholder farmers.

A case study approach was used in the research. This aims to provide information from only one case and is usually characterised by the use of qualitative data. A case study of SEDCO provides accurate information in the field of microcredit financing as it made use of already available data. It allows the gathering of information from representatives of a large population, and the information could be accurate within sampling error ranges. In addition, a case study provides rich detail of a predominantly qualitative nature.

\section{Target Population: All SMEs in Harare were the target population}

Sample: Since it was not possible to cover the whole population, a sample of thirty clients was selected for data collection concerning the reasons for defaults and concerning the factors influencing timely repayment by borrowers.

\section{DATA ANALYSIS AND DISCUSSION}

Types of businesses operated by respondents: The table below show the types of businesses operated by the respondent who took part in the research:

Table 4.2: Businesses operated by borrowers

\begin{tabular}{|l|l|}
\hline Type of business operated by respondent & Percentage \\
\hline Sole traders & $32 \%$ \\
\hline Partnership & $21 \%$ \\
\hline
\end{tabular}




\begin{tabular}{|l|l|}
\hline Private companies & $25 \%$ \\
\hline Co-operatives & $14 \%$ \\
\hline Other businesses & $8 \%$
\end{tabular}

Out of the SME's who responded to the questionnaires $32 \%$ of the were sole traders, $21 \%$ were operating partnership businesses, $25 \%$ operated registered private companies and $14 \%$ and $8 \%$ of them operated co-operative and other businesses respectively. This showed that most of the sole traders, partnerships and private companies have been able to meet the requirements that are need in order to access a loan from SEDCO.

\section{Fig 4.5: Repayment status of borrowers}

The above graph shows the percentages of the repayment status of borrowers. Comparison was made between SEDCO's secondary data and the selected SMEs who took part in the research. According to SEDCO's statistics out of the total disbursements made for the period of study, an average of $27 \%$ of the borrowers are early re-payers, $17 \%$ are slow re-payers and $56 \%$ are defaulters.

However a significant difference was shown by the results from the slow re-payers. A total percentage of thirty-two of the respondent were slow re-payers as compared to $17 \%$ from the data collected from SEDCO.

\section{Factors considered when screening loan applicants}

From the information gathered from the SME's it was found that for one to get a loan from SEDCO one has to meet the following requirements as illustrated in the graph below:

Fig 4.6: Factors considered in loan screening

The findings show that for one there is need to pledge assets as collateral and one has to operate a viable project and convince the lender using a viable business plan that this project will be able to generate enough cash flows to repay the loan.

According to the Projects Manager, Harare Branch Manager and Risk Manager of SEDCO, the following has been found to be the most important factors that are considered when evaluating the credit worthiness of loan applicants in the microfinance industry:

- How financially aware is the client?

- Is there any security?

- Previous performance of the clients business

- Performance of the business with other businesses for example its creditors.

- Project viability

Before one is considered for a loan a multistage project appraisal is carried out. This is done to ensure that the defaults and delinquencies are minimised and to ensure that only viable projects are financed.

\section{Average time required to access a loan form SEDCO}

\section{Fig 4.7: Time required in accessing a loan}

Fig 4.7 shows that most of the loan applicants are taking one hundred and twenty days on average to get a loan. It is therefore evident that it requires a long time to get a loan from the date of submission of the loan application to the date when the funds are disbursed to the client. Explanations from SEDCO staff for the delays in disbursement are as a result of the 
multistage project appraisal process. This process takes long as it is bureaucratic and involves a risk decision and hence there is need to be careful.

\section{Fig 4.8: Stages in project appraisal}

From the results on the reasons why borrowers are failing to make repayment in time, other borrowers say that they are failing to make repayment in time because of delays in loan disbursement. On time disbursement of funds allows borrowers to match acquired fund use and the needs of the business. Untimely disbursement is the leading factor to diversion of funds.

\section{Credit operation of SEDCO}

The information below relates to the loan operation of SEDCO in the period 2009-2012. The information provided is on the amounts that were disbursed, loan demands based on total applications received, the amounts that the institution was able to collect and loans which were not recovered at the end of each financial year.

Table 4.4: Credit operation (amounts in US\$ million)

\begin{tabular}{|l|l|l|l|l|l|}
\hline Year & $\begin{array}{l}\text { Amount } \\
\text { disbursed }\end{array}$ & $\begin{array}{l}\text { Amounts } \\
\text { collected }\end{array}$ & $\begin{array}{l}\text { Loan } \\
\text { outstanding }\end{array}$ & $\begin{array}{l}\text { Loan in } \\
\text { arrears }\end{array}$ & $\begin{array}{l}\text { Loan } \\
\text { demand }\end{array}$ \\
\hline 2009 & 19.35 & 2.86 & 32.67 & 22.69 & 20.67 \\
\hline 2010 & 17.52 & 5.28 & 42.67 & 19.51 & 35.26 \\
\hline 2011 & 20.32 & 10.23 & 45.32 & 7.65 & 48.67 \\
\hline 2012 & 14.67 & 4.60 & 57.42 & 27.4 & 35.12 \\
\hline
\end{tabular}

From table 4.4 loan demand is always higher than the total amounts disbursed. This shows that there is some screening that is done before loans are extended to beneficiaries. From the graph it can be deduced that an increase in the amounts collected resulted in an increase in the amounts disbursed and the reverse is also true. The table also show that loan collection was poor as compared to the outstanding amounts which increase rapidly on a yearly basis.

\section{Fig 4.9: Credit operations of SEDCO}

According to the SEDCO officers who were interviewed, the decline in the loan disbursement can be explained by the liquidity crunch that was experienced in the overall economy of Zimbabwe during the period under review. This also resulted in the rapid increases in the outstanding loans as the economic conditions were not conducive for any business. The SMEs were failing to make repayment in time and most of them were in default.

The reasons cited by SEDCO management are contrary to those given by Kohansal and Mansoori, (2011). They cited that a number of economic and market inadequacies lead to defaulting. These inadequacies include:

a. Interest rate ceiling usually imposed by the government

b. Monopoly power in credit markets often exercise by informal lenders

c. Large transaction costs incurred by borrowers in applying for loans

d. Moral hazard problem

\section{Loan repayment performance}

Loan repayment is indicated by the recovery rate and the arrears to outstanding. A decrease in the arrears to outstanding ratio shows an improvement in the repayment performance in any period and the reverse is an indication of poor repayment performance. From table 4.5 below 
it is shown that the repayment has been good during the 2009/10 and 2010/11 period and the period 2011/12 showed a poor result. Instead of using the latter ratio, the recovery rate also measures repayment performance. An increase in the recovery rate is a sign of good performance and a decrease mean poor repayment performance.

Table 4.5: Comparison of arrears to outstanding ratio and recovery rate

\begin{tabular}{|c|c|c|}
\hline Year & Arrears to outstanding ratio & Recovery rate \\
\hline 2009 & $69.5 \%$ & $13.8 \%$ \\
\hline 2010 & $45.7 \%$ & $15.0 \%$ \\
\hline 2011 & $16.9 \%$ & $21.1 \%$ \\
\hline 2012 & $47.7 \%$ & $13.1 \%$ \\
\hline
\end{tabular}

The findings show that the arrears to outstanding ratio decreased from 2009 to 2011 period but in rose in the year 2012 to $47.7 \%$. This was not the case for the recovery rate which increased as the arrears to outstanding ratio decreased and increased as the ratio decreased. Therefore there is an inverse relationship between the arrears to outstanding ratio and the recovery ratio.

The major loan repayment performance indicators of SEDCO are the arrears to outstanding ratio and the recovery rate. These are used to indicate how efficient the financial institution is in collecting loan repayment. During the period 2009-2011 the arrears to outstanding ratio declined drastically from $69.5 \%$ to $45.7 \%$ during 2009 to 2010 and then to $16.9 \%$ in 2011 . This was due to a continuous increase in the outstanding amounts and decreases in the loans that were in arrears at the end of each year. However the arrears to outstanding amounts ratio had a sharp increase during the 2011/12 period. This was as a result of poor implementation of the credit policy in debt management and this was also as a result of the poor liquidity position of the organisation as it failed to collect more during the period.

During the periods 2009-2010 and 2011-2012 the loan recovery rate was very poor. This meant that SEDCO was unable to collect large amounts of loans that were due for the periods. In the period 2010-2011 the loan recovery rate increased from $15.0 \%$ to $21.1 \%$ showing an improvement in the collection during the year.

Arrears to outstanding ratio $=$ Loan in arrears

$$
\text { Loan outstanding }
$$

Recovery rate $=$ Amounts collected

$$
\text { Loan demand }
$$

\section{Reasons behind loan repayment performance}

Table 4.6 and fig 4.11 below show the reasons why borrowers are finding it difficult to meet their loan repayment. Most of the respondents agree with the fact that poor repayment is as a result of having many dependents, poor business performance and diversion of funds to unprofitable use.

Table 4.6: Causes of repayment problems

\begin{tabular}{|l|c|c|c|c|}
\hline & Strongly agree & Agree & Disagree & Strongly disagree \\
\hline Many dependence & 13 & 10 & 4 & 1 \\
\hline Business closed & 2 & 18 & 6 & 2 \\
\hline $\begin{array}{l}\text { Poor business } \\
\text { performance }\end{array}$ & 11 & 13 & 4 & 0 \\
\hline
\end{tabular}




\begin{tabular}{|l|l|l|l|l|}
\hline Diversion of funds & 6 & 17 & 2 & 3 \\
\hline Poor timing & 7 & 14 & 3 & 4 \\
\hline Theft/ robbery & 7 & 11 & 6 & 4 \\
\hline Domestic problems & 6 & 15 & 6 & 1 \\
\hline
\end{tabular}

Moreover some borrowers gave other reasons as to why they are failing to make repayments. The following are some of the reasons:

- Loss of jobs - borrowers lost other sources of income that could be used to pay up the loans.

- Legal requirements - the payment of trading licenses impacted negatively on the cash flow position of the business and hence causing problems in meeting repayment deadlines.

- Poor financial planning - this was as a result of lack of knowledge of how business are conducted.

- Operation of the wrong business in an area - this is involves poor marketing of the business products.

- Rent and rates - these also pose some problems on the cash flow of the business.

- Interest rates are high - some clients complained that the interest rates were very high in such a way that they failed to pay both the principal repayment and interest as per borrowing terms.

- Short repayment period - borrowers are expected to make repayment instalments within a month's time.

According to Kohansal and Mansoori (2011) most of the defaults arose from poor management procedures, loan diversion and unwillingness to pay loans. This is indicated by the results as most of the respondents agreed and strongly agreed to the above discussed factors.

From the microfinance institutions point of view the major contributing factors to poor repayment are delays in disbursement of funds which leads to diversion of funds to other reasons that they were not intended for. The delays in disbursement are most as a result of the multi-stage project appraisal process.

Another factor that lies with the lender is that the institution has poor information systems which make it difficult for the institution to make client follow ups before they are in default. The system is old and is no longer compatible with the increasing information needs of the institution. Furthermore the client accounts are usually not updated in time and the system is in compatible with the information needs of the corporation. The system does not allow to update back dated receipts of repayment and this causes problems in tracing borrowers' repayment status.

Moreover the institution highlighted that loan repayment depends on the availability of other sources of income of the borrowers. Borrowers who depend on other sources of income rather than that generated from the small businesses they operate are likely to make early repayment.

\section{Implementation of the credit policy}

Most of respondents believe that the administration of borrowers at SEDCO is ineffective. This is represented by an $82 \%$ response to this fact. Ineffective administration of borrowers is mostly because there has been no monitoring of clients business during the years and clients account statements are not being prepared. 


\section{Fig 4.12: Effectiveness of the credit policy}

According to the interviews carried out and questionnaires administered at SEDCO, the credit policy was reviewed annually and sometimes the policy changes were determined by the economic conditions (i.e. average industry interest rates, loan demand and loan performance) and legislation (since SEDCO is regulated by the Ministry of Small to Medium Enterprises and Cooperative Development and the Reserve Bank of Zimbabwe).

The above results are in line with what Pandey (2010) has suggested. A typical credit policy should neither be too liberal or too restrictive. According to Pandey (2010) a liberated credit policy will increase the amount of sale and profitability. But risk will also increase with increase in sales.

The SEDCO credit policy stipulates that clients business should be visited once every quarter as a post-disbursement risks management measure. However this is not being implemented as evidenced by the research because most of the SMEs' businesses were not being monitored at all. This was explained by the management as being a result of lack of working capital. During the past years SEDCO has been experiencing poor cash flows and the liquidity ratio has been below the acceptable level because of poor repayment collections.

\section{MEASURES TO IMPROVING LOAN REPAYMENT PERFORMANCE}

\begin{tabular}{|l|c|c|c|c|}
\hline & Strongl & & & $\begin{array}{c}\text { Strongl } \\
\text { y } \\
\text { disagre } \\
\text { y agree }\end{array}$ \\
\hline Reduce interest rates & 12 & 13 & 2 & 1 \\
\hline Extend repayment period & 10 & 15 & 2 & 1 \\
\hline Group lending & 0 & 1 & 15 & 12 \\
\hline $\begin{array}{l}\text { Monitoring by SEDCO } \\
\text { Education on business } \\
\text { management }\end{array}$ & 14 & 7 & 4 & 3 \\
\hline $\begin{array}{l}\text { Improve } \\
\text { administration }\end{array}$ & 15 & 9 & 9 & 2 \\
\hline $\begin{array}{l}\text { Education on government } \\
\text { microcredit programs }\end{array}$ & 12 & 12 & 0 & 4 \\
\hline & & & & \\
\hline
\end{tabular}

The results show reduction of interest rates, extension of repayment period and education on government on microcredit programs will result in an improvement loan repayment among borrowers. However table 4.7 above also show that the respondents disagree with group lending, as a way of improving repayment. This is because group lending is associated with conflict. Group members may disagree in making repayment as they have different interests and priorities.

On the contrary, group lending has proved to be effective in ensuring a health loan repayment performance to the Grameen Bank as it has been able to recover more than $90 \%$ of its loans since its inception. From this regard the Grameen Bank has been ranked one of the most successful microcredit institutions globally.

\section{Fig 4.13: Ways of improving loan repayment}

From the SEDCO's point of view reduction of interest rates will affect the company's profitability levels and liquidity position so most of the respondents from SEDCO disagreed 
with the fact as a way of improving loan repayment. Their main argument was that SEDCO is one of the financial institutions in Zimbabwe which offers the lowest interest of 15\% per annum as compared to other institutions which offer an average of $24 \%$. Therefore a reduction in interest rates will compromise its financial positions. In order to encourage timeous repayment SEDCO has put in place the following measures in place:

- Entrepreneurial training for borrowers

- Making reminders by telephone and door to door repayment collection

- Threaten to take legal action and dispose assets pledged as collateral

- Charging a punitive interest rate of $40 \%$ rather than the normal rate of $15 \%$

- Encourage the borrowers to make early repayment so that they can be allowed to get another loan.

\section{CONCLUSIONS AND POLICY RECOMMENDATION CONCLUSIONS}

- The financial institution has been reluctant to extend loans to those borrowers who do not meet the institutions lending requirements. This was also evidenced by the findings of the study and another author Deacons (2007) who carried out a research on the microcredit challenges in California.

- Collateral, project viability and a viable business plan are found to be the major factors considered for loan screening. This was also supported by a research carried out by Roslan and Karim (2010) on the Agrobank in Malaysia. On the contrary, Afolabi (2010) and Okpukpara (2009) found that the socio-economic factors are the most important factors in loan screening. Moreover Coravos (2010) emphasised that risk could not be looked at in negligence in evaluating creditworthiness of borrowers.

- Loan diversions to unprofitable use, poor business performance and the number of dependents that a borrower has are the major reasons why borrowers are finding it difficult to meet repayment deadlines. Other researchers who supported this view were Kohansal and Mansoori (2011), Okpukpara (2009), Ojiako and Ogbukwa (2012).

- Loan repayment performance is measured in terms of the arrears to outstanding ratio the loan recovery rate. These ratios are also used by the National Bank of Ethiopia (NBE) as cited in case study by Gebeyehu (2009). However Ajiambo (2010) suggested that repayment performance is determined by average repayment delay and default rate.

- Credit policy implementation is poor as a result of lack of working capital. This was supported by the Pandey (2010) and the Risk and Finance Manager of SEDCO.

\section{RECOMMENDATIONS}

- Loan screening should be devised in such a way that allows micro and small scale entrepreneurs who have the necessary entrepreneurship capacity and managerial skills to have access to formal credit even though they do not have assets to pledge as security.

- Repayment periods should be set in consideration of financial viability of the projects that are being considered for financing, the size of the loan, the market and economic conditions.

- Client follow ups should be intensified so that borrowers are encouraged to make early repayment and client business should be monitored to ensure that entrepreneurial skills are constantly improved. 
- Clients should be educated on how they view government credit programs. Borrowers should be notified of the fact that the funds extended to them should be repaid in time because they are not government grants.

- SEDCO should improve its loan management information system in such a way that it is able to produce up to date client statements. The system should enable early detection of potential default problems.

\section{References}

Afiolabi J.A., (2010), “Analysis of Loan Repayment among Small Scale Farmers", Journal of Social Sciences, Vol 22(2), pp. 115-119

Ajiambo R., 2010, “Causes Of Default in Government Microcredit Programs”, World Bank Institute, Washington DC, Vol 23, pp. 253-64

Awoke M.U., (2004), “Factors Affecting Loan Acquisition Repayment Patterns of Smallholder Farmers”, Journal of Sustainable Tropical Agricultural Research, Vol 9: 61-64

Bullivant G, (2013), FECMA credit policy

Chirwa E.W. (2009), “An Econometric Analysis of Determinants of Agricultural Credit Repayment in Malawi, African Review Of Money And Banking", Supplement Of The Savings And Development Journal,Vol 1(2),107-119.

Coravos A, R, (2010). “Community Development Financial Institutions and the Use of Credit Scoring To Minimise Default Risk", Duke University

Cowan C and Cowan A, (2006), "A Survey Based Assessment of Financial Institution Use of Credit Scoring for Small Business Loans", Office Of Advocacy, US Small Business Administration, Retrieved September 15, 2009

Deacons J.L (2007), “The Micro-Credit Challenge: A Survey of Programs In California”, Journal Of Developmental Entrepreneurship,Vol 6(1), pp. 1-16

Dyrberg R (2005), “Accounting Based Credit Scoring Models", Econometric Investigations, PhD thesis, Dunmarks National Bank.

Gebeyehu A (2009), Loan Repayment and Determinants in Small Scale Enterprises Financing In Ethiopia, Journal of Economic Development, Vol 3(1) Pp204-373

Glennon D And Nigro P (2005), "An Analysis of SBA Loan Default by Maturity Structure." Journal of Financial Services Research.vol 28, no 1/2/3, pp. 77-111

Haile M, (2011), Factors Affecting Loan Repayment Performance of Small Holder Farmers,

Horne V, (2003), Fundamentals of Financial Management, 11th edition, Prentice hall, London

Huppi M and Feder G (2009), "The Role of Group and Credit Co-Operative in Rural Lending." World Bank Research Observer, Vol 5(2), pp. 187-204

Kohansal M and Mansoori H, (2011), "Factors Affecting Loan Repayment Performance In Khorasan-Razavi Province Of Iran", Conference Study On International Research On Food Security. Accessed October 8, 2009

Koopahi M and Bakhashi M R, (2010), "Factors Affecting Agricultural Credit Repayment Performance”, Iranian Journal of Agricultural Sciences, 33, 1, 11-19

McCann F and McIndoe-Calder, (2012), "Determinants of SME Loan Default: The Importance of Borrower-Level Heterogeneity", Journal Of Finance, Vol 23(4), 479-506

Mester L,(2011), “What's the point of credit scoring? Business review”, Federal Reserve Bank of Philadelphia, pp.3-16

Mishi S and Kapingura F, (2012), “Women's Access to Microfinance and Poverty Alleviation in Zimbabwe: Case of Chinhoyi Town", Journal of Business Management, Vol 6 (29), pp. 667-76

Norell D (2011), "How to Reduce Arrears in Microfinance”, Journal of Micro Finance, Vol 3(1), pp. 115-130.

Ogbukwa C and Ojiako I.A, (2012), Economic Analysis of Loan Repayment of Smallholder Cooperative Farmers Yewa North Nigeria, African Journal of Agricultural Research, Vol 7(13) pp. 2051-62, Accessed February 13, 2012 
Gutu. G. J., Nyakuwanika. M., Matowanyika. K., \& Unganayi. M. (2015). An analysis of Loan repayment Performance in Government Microcredit Programs: A Case of Small Enterprises Development Corporation (SEDCO) in Zimbabwe (2009-2012). Archives of Business Research, 3(2), 54-72.

Okupukpara B, (2009), "Strategies for Effective Loan Delivery to Small Scale Enterptises in Rural Nigeria”, Journal of Development an Agricultural Economics, Vol 1(2), pp. 41-48, Accessed May, 2009

Pandey I.M, (2010), Financial Management, 8thedition, Vikas Publishing House Pvt Ltd.

Pischke V (2011), "Finance at the Frontier: Debt Capacity and the Role of Credit in the Private Economy", The World Bank, Washington DC

Roslan A.H And Karim M.Z,(2009), “Determinants of Repayment in Malaysia: Case Of Agrobank”, Journal Of Humanity And Social Sciences,Vol 4(1), pp. 45-52.

Stanford M F, (2010), “Trade Credit In Zimbabwe”, Journal Of Development Studies, Vol 32(2), pp. 276-298

Wenner M (2011), “A Means to Improve Information Transfer and Loan Repayment Performance”, Journal of Development Studies, Vol32(2),pp 264-81.

Yunus M (2003), Bankers to the Poor: Micro-lending and the Battle against World Poverty, New Work, Public Affairs. 